\title{
KETEDASAN TERJEMAHAN AYAT-AYAT IMPERATIF BERNUANSA BUDAYA
}

\author{
Mohamad Zaka ACFarisi \\ Universitas Pendidikan Indonesia \\ Email: zaka@upi.edu
}

\section{Abstract}

Each language has its own uniqueness because of the existence of cultural concepts that exist in it. To bring clarity to the translation of the nuanced cultural speech, including those contained in the imperative verses, often becomes an obstacle in translation. The study, which used a qualitative-evaluative approach with the design of embedded case study research, aims to reveal the clarity of the translation of imperative verses that have cultural nuance meanings. Samples were selected purposively regarding imperative verses that have specific pragmatic meanings. The clarity of the translation of the imperative verses relies on the techniques and procedures of translation applied in dealing with micro-translation units. Couplet procedure that combines literal and amplification techniques may fulfill clarity aspect in translation.

Setiap bahasa mempunyai keunikan tersendiri berkat keberadaan konsep-konsep budaya yang ada di dalamnya. Dalam penerjemahan, menghadirkan ketedasan terjemahan tuturan yang bernuansa budaya, termasuk dalam ayat-ayat imperatif, seringkali menjadi kendala tersendiri. Penelitian ini, yang menggunakan pendekatan kualitatif-evaluatif dengan desain studi kasus terpancang, bertujuan untuk mengungkap ketedasan terjemahan ayat-ayat imperatif yang bernuansa budaya. Sampel penelitian dipilih secara purposif berupa ayat-ayat imperatif yang memiliki makna pragmatik tertentu. Ketedasan terjemahan ayat-ayat imperatif tidak terlepas dari teknik dan prosedur penerjemahan yang diterapkan dalam menangani unit-unit mikro terjemahan. Prosedur kuplet yang memadukan 
teknik literal dan teknik amplifikasi dapat menghadirkan ketedasan terjemahan yang berterima.

Keywords: clarity; imperative passages; translation

\section{Pendahuluan}

Larson (1998) menekankan pentingnya aspek budaya dalam penerjemahan. Menghadirkan ekuivalensi dalam penerjemahan tidaklah mudah, sebab ekuivalensi tidak hanya berhubungan dengan aspek bahasa tetapi juga dengan aspek budaya. Mengalihkan pesan teks sumber yang relatif sepadan dalam teks terjemahan itu memerlukan keperigelan khusus. Selain menyangkut penguasaan bahasa/budaya bahasa sumber (BS) dan bahasa target (BT), mutu sebuah teks terjemahan juga bertemali dengan kemampuan transfer yang andal. Yang terakhir ini antara lain berkaitan dengan penguasaan teori-teori penerjemahan. Menurut Larson (1998), menerjemahkan berarti (1) mengkaji BS dari aspek leksikon, struktur gramatika, situasi komunikasi, dan konteks budaya; (2) menganalisis BS untuk mendapatkan makna yang dikehendaki penulisnya; (3) mereproduksi makna tersebut dengan memakai leksikon, struktur gramatika, dan konteks budaya yang sesuai dalam BT. Dalam praktiknya bisa dipastikan penerjemahan selalu melibatkan aspek-aspek bahasa dan budaya. Keterlibatan bahasa dan budaya meniscayakan penerjemahan bukan semata merupakan pengalihan bentuk dan makna, melainkan juga pengalihan aspekaspek budaya. Thriveni (2002) berpendapat bahwa makna yang berkonteks budaya terajut sangat rumit (intricately woven) dalam tekstur bahasa. Penerjemah harus mempunyai ketelitian dalam menghadapi dan menyikapi dua budaya yang berbeda. Sudah menjadi keharusan penerjemah dapat menangkap aspekaspek budaya yang terdapat dalam BS seraya menuangkannya kembali dalam BT yang berterima menurut pembaca target.

Kesenjangan bahasa dan budaya pada gilirannya menyisakan persoalan ketakterjemahan (untranslatability). Akan ada aspek-aspek bahasa dan budaya yang tidak teralihkan dalam BT. Supaya bisa menerjemahkan tuturan bernuansa budaya secara tedas, menurut ash-Shawi (2013), penerjemah harus mempunyai pengetahuan tentang budaya BS dan BT. Penelitian Shanmugam (2010), misalnya, menyebutkan bahwa peribahasa dalam pantun berbahasa Malayu boleh jadi mencandrakan pemikiran yang bersifat universal. Namun, peribahasa-peribahasa tersebut seringkali dikemas dalam penggambaran bahasa metaforis yang unik dalam bahasa Melayu. 
Sekaitan dengan penerjemahan al-Quran, penelitian Al Farisi (2010) menyebutkan bahwa terjemah Kemenag (al-Qur'an dan Terjemahnya) menggunakan teknik literal lebih dari 60,0\% dalam menangani ayat-ayat iltifat. Menurut Al Farisi (2015), kecenderungan literal ini tidak terlepas dari ideologi forenisasi terjemah Kemenag yang mendasari penerjemahan ayat-ayat iltifat. Menurut Huzairi \& Ibrahim (2009), terdapat perbedaan mendasar sekaitan dengan penerjemahan wacana keagamaan antara umat Kristen dan umat Islam. Yang pertama lebih berorientasi kepada BT, sedangkan yang kedua lebih berorientasi kepada BS. Di satu pihak umat Kristen memandang bahwa terjemahan Injil memiliki kesucian yang sama dengan Injil dalam bahasa aslinya, dan di pihak lain umat Islam memandang terjemahan al-Quran sama sekali tidak sepadan dengan al-Quran dalam bahasa aslinya. Terjemah al-Quran hanya dipandang sebagai upaya untuk menjelaskan al-Quran, terutama kepada pembaca yang tidak memahami bahasa Arab.

Penelitian Garces (2008) menyebutkan bahwa ungkapan-ungkapan yang berhubungan dengan khayalan, perasaan, dan humor yang terdapat dalam buku Harry Potter ternyata tidak selalu terterjemahkan ke dalam BT, bahkan ada yang sama sekali tak terterjemahkan. Al Farisi (2013) mengungkapkan bahwa 93,3\% pembaca terjemah Kemenag tidak memerlukan upaya pemrosesan (processing effort) yang rumpil untuk memahami maksud terjemahan ayat-ayat kinayah yang memuat ungkapan tabu tentang berjimak. Penelitian Seong (2011) menerangkan sulitnya mencari ekuivalensi makna verba bahasa Cina dalam bahasa Melayu. Sebuah verba dalam bahasa Cina yang bermakna mengemukakan kata-kata ternyata memiliki ekuivalensi yang beragam dalam bahasa Melayu, yaitu bercakap, berujar, berkata, atau menyebut. Oleh sebab itu, pendekatan rasionalis terhadap makna sulit dijadikan pijakan dalam penerjemahan. Masalahnya, sebagaimana diungkapkan Xiao-yan (2013), kesalahan terjemahan lazim diakibatkan oleh keputusan penerjemah yang tidak tepat dalam mereproduksi konsep-konsep budaya yang bersifat spesifik dalam BT.

\section{Aspek Ketedasan dalam Penerjemahan}

Teks terjemahan yang tidak memenuhi aspek ketedasan bisa dipastikan sulit dimengerti atau tidak dapat dipahami sama sekali. Aspek ketedasan berhubungan dengan seberapa mudah/sulit pembaca memahami informasi yang termaktub dalam BT. Dengan kata lain, aspek ketedasan bertemali dengan keterbacaan (readability) sebuah teks terjemahan. Teks terjemahan yang

el Harakah Jurnal Budaya Islam Vol. 19 No.2 Tahun 2017 
memiliki derajat ketedasan yang tinggi tentu mudah dipahami. Sebaliknya, teks terjemahan yang memiliki derajat ketedasan yang rendah tentu sulit dipahami. Menurut Sakri (2006), ada dua istilah yang berhubungan dengan keterbacaan sebuah teks, yaitu ketedasan dan kejelahan. Ketedasan berhubungan dengan keterbacaan bahasa yang ditentukan oleh pilihan kata, konstruksi kalimat, susunan paragraf, dan unsur ketatabahasaan yang lain. Sedangkan yang kedua, kejelahan, berhubungan dengan keterbacaan tata huruf yang mencakup besar/kecil huruf, kerapatan baris, lebar sembir, tata letak, tipografi huruf, dan unsur tata rupa lainnya.

Ketedasan terjemahan antara lain dipengaruhi oleh panjang-pendek konstruksi kalimat. Lazimnya panjang-pendek kalimat dalam sebuah teks terjemahan dipengaruhi oleh panjang-pendek kalimat yang terdapat dalam teks sumbernya. Idealnya konstruksi kalimat dalam sebuah teks terjemahan bersifat semenjana dari segi pilihan kata, struktur kalimat, dan terutama panjangpendek kalimat. Kalimat rumpil yang terlalu panjang cenderung mengganggu ketedasan terjemahan. Menurut Flesch (2005), rerata panjang kalimat yang terdiri atas 17 kata bisa menghadirkan wacana dengan ketedasan yang baku. Selain itu, ke(tak)tedasan terjemahan boleh jadi juga disebabkan oleh faktor ketaksaan, baik pada tataran leksikal, gramatikal, maupun stilistika. Dalam pandangan Al Farisi (2011), derajat ketedasan terjemahan bersinggungan dengan aspek-aspek linguistik semisal penggunaan kategori sintaksis (verba, nomina, ajektiva, pronomina, numeralia); penempatan fungsi sintaksis (subjek, predikat, objek, keterangan, pelengkap); serta pemilihan diksi, preposisi, kopula, kolokasi, pungtuasi, dan semacamnya.

Dari paparan tersebut tampak bahwa ketedasan terjemahan berhubungan dengan unsur-unsur yang hadir dalam sebuah teks terjemahan yang meliputi penggunaan diksi, konstruksi kalimat, dan sebagainya. Penggunaan diksi yang berasal dari kata-kata asing atau daerah yang kurang popular jelas akan memengaruhi ketedasan terjemahan. Istilah efektif dan efisien yang berasal dari bahasa asing, misalnya, lebih populer ketimbang kata sangkil dan mangkus yang berasal dari bahasa daerah. Penggunaan diksi efektif dan efisien sudah barang tentu lebih menghadirkan ketedasan ketimbang diksi mangkus dan sangkil yang kurang populer. Konstruksi kalimat yang panjang-panjang, sebagaimana disebutkan, juga dapat mengganggu ketedasan terjemahan. Richards dkk. (2005: 238) berpendapat bahwa ketedasan sebuah wacana, termasuk terjemahan, bergantung pada "how easily written materials can be read and understood". Ketedasan terjemahan bisa ditelaah dengan mengukur rerata 
panjang kalimat, kerumpilan struktur kalimat, dan jumlah kosakata baru yang dipergunakan. Untuk mengukur derajat ketedasan, penerjemah dapat meminta tanggapan sejumlah responden yang tidak menguasai BS untuk mengikuti uji komprehensi atas sebuah teks terjemahan. Uji komprehensi bertujuan untuk mengetahui pemahaman pembaca terhadap sebuah teks terjemahan. Menurut Larson (1998), uji komprehensi terjemahan seyogianya didesain untuk menggali sejauhmana sebuah teks terjemahan mengomunikasikan informasi yang dikehendaki oleh penulis teks sumbernya. Uji komprehensi dimaksudkan untuk mengungkap sejauhmana pembaca dapat menceritakan kembali informasi yang terdapat dalam sebuah teks terjemahan. Dalam hal ini pembaca diminta untuk menjawab sejumlah pertanyaan yang berhubungan dengan teks terjemahan tersebut. Hasil uji komprehensi dapat digunakan untuk meminda teks terjemahan supaya menjadi lebih tedas.

Aspek ketedasan juga berkaitan dengan segmentasi pembaca target. Lazimnya pembaca target menjadi pertimbangan penerjemah dalam menentukan diksi, konstruksi kalimat, dan sebagainya. Sebagai contoh terjemahan yang diperuntukkan bagi segmen pembaca anak-remaja tentu harus lebih mengutamakan diksi yang akrab dengan dunia mereka, menggunakan kalimat yang pendekpendek, dan menghadirkan konstruksi kalimat tidak rumpil. Dalam praktik boleh jadi penerjemah mesti menyederhanakan sebuah kalimat yang rumpil ke dalam dua atau tiga kalimat yang lebih semenjana dalam BT. Cara ini akan lebih mangkus dan sangkil apabila ditunjang tataletak yang jelah, termasuk pemilihan ukuran kertas, lebar sembir, spasi, tipografi huruf, dan semacamnya.

\section{Tuturan Imperatif dalam BA dan BI}

BA (bahasa Arab) mengelompokkan kalam (tuturan) ke dalam dua kategori, yaitu kalam khabariy dan kalam insya'iy. Yang pertama, kalam khabariy, adalah tuturan yang mengandung kemungkinan benar atau salah. Istilah kalam khabariy relatif sepadan dengan tuturan konstatif yang dikemukakan John Langsaw Austin pada 1960an. Tuturan konstatif adalah tuturan yang mendeskripsikan atau melaporkan suatu peristiwa atau keadaan di dunia. Dalam hal ini tuturan konstatif mempunyai kemungkinan untuk dikatakan sebagai tuturan yang benar atau salah (lihat Cummings, 2005). Matahari terbit dari timur termasuk kalam khabariy lantaran menghadirkan kemungkinan benar atau salah. Disebut benar, jika proposisi tuturan tersebut sesuai dengan realitas yang ada di luar bahasa; disebut salah, jika proposisi tuturan tersebut tidak sesuai dengan realitas yang ada di luar bahasa.

el Harakah Jurnal Budaya Islam Vol. 19 No.2 Tahun 2017 
Kedua, kalam insya'iy, adalah tuturan yang tidak mengandung kemungkinan benar atau salah. Istilah kalam insya'iy relatif sepadan dengan tuturan performatif yang juga digagas John Langsaw Austin. Berbeda dengan tuturan konstatif tersebut, tuturan performatif tidak mendeskripsikan dan tidak melaporkan suatu peristiwa atau keadaan di dunia, dan karenanya tidak memiliki kemungkinan benar atau salah (lihat Cummings, 2005). Tuturan imperatif, "Masuk!" merupakan kalam insya'iy lantaran tidak menghadirkan kemungkinan benar atau salah. Dengan kata lain, kalimat tersebut tidak memiliki kemungkinan untuk diverifikasi kebenarannya. Kita tidak bisa mengatakan, kalimat Masuk! sesuai atau tidak sesuai dengan realitas di luar bahasa. Yang ada, tindakan masuk itu belum terealisasi saat tuturan tersebut diucapkan, sebab jika tindakan masuk sudah terealisasi, niscaya penutur tidak akan mengatakan, "Masuk!" Hal yang sama juga berlaku, antara lain, untuk kalimat interogatif, "Apakah si fulan sudah masuk?" Kalimat ini juga tidak mengandung kemungkinan benar atau salah. Dalam hal ini penutur bermaksud untuk mencari tahu apakah si fulan sudah masuk atau belum. Sekiranya penutur mengetahui si fulan sudah masuk, niscaya ia tidak akan bertanya, "Apakah si fulan sudah masuk?"

Selanjutnya kalam insya'iy terbagi lagi ke dalam dua kategori, yaitu insya'iy thalabiy dan insya'iy ghair thalabiy. Pertama, insya'iy thalabiy adalah tuturan yang digunakan untuk meminta sesuatu yang menurut keyakinan penutur belum terealisasi pada saat tuntutan tersebut dikemukakan (al-Hasyimi, 2001). Insya'iy thalabiy, yang notabene merupakan kajian utama dalam ilmu Ma'ani, mencakup lima wujud tuturan, yaitu al-amr (imperatif), al-nahy (prohibitatif), al-istifham (interogatif), al-tamanniy (optatif), dan al-nida' (vokatif). Kedua, insya'iy ghair thalabiy adalah tuturan yang tidak menuntut sesuatu tindakan yang belum terealisasi saat tuturan tersebut dikemukakan. Insya'iy ghair thalabiy mencakup bentuk-bentuk tuturan al-madhu wa al-dzamm (pujian dan celaan), al-uqud (akad), al-qasam (sumpah), at-ta'ajjub (kekaguman), al-raja' (harapan), dan sebagainya.

Dari paparan di atas tersebutlah bahwa al-amr (imperatif) dalam BA termasuk tuturan insya'iy thalabiy. Secara umum al-amr berisi thalab (tuntutan) supaya mitra tutur melakukan sesuatu tindakan yang dikehendaki penutur. Dalam BI (bahasa Indonesia) terdapat beberapa istilah yang lazim dipakai untuk menyebut al-amr. Verhaar (2008) dan Rahardi (2010) memakai istilah imperatif. Istilah imperatif, selain merujuk kepada kalimat imperatif, juga digunakan untuk menyebut bentuk verba yang dipakai dalam kalimat imperatif. 
Alisjahbana (1978), Keraf (1980), dan Moeliono (1992) memakai istilah kalimat perintah sebagai padanan al-amr. Pakar lain seperti Slametmuljana (1959), Poedjawijatna \& Zoetmulder (1964), dan Ramlan (1987) menyebut alamr sebagai kalimat suruh. Dalam BI, wujud formal imperatif bisa dibedakan berdasarkan verba yang hadir dalam suatu kalimat, yaitu imperatif pasif dan imperatif aktif. Imperatif berdiatesis pasif digunakan untuk mengungkapkan derajat suruhan yang relatif rendah. Imperatif aktif, baik aktif taktransitif maupun aktif transitif, bisa dibentuk dari tuturan deklaratif dengan cara-cara berikut. Pertama, melesapkan subjek berupa persona kedua (lihat Verhaar, 2008). Kedua, memertahankan bentuk verba yang dipakai dalam tuturan deklaratif. Dan ketiga, menyisipkan partikel lah guna memerhalus tuturan (Rahardi, 2010).

Menurut Ghalayaini (2010), takrif al-amr adalah tuntutan direalisasikannya suatu tindakan yang belum terealisasi pada saat tuntutan tersebut disampaikan. Realisasi wujud formal imperatif dalam BA bisa berupa:

1. Verba amar (fi'lu al-amr) sebagaimana kata ${ }^{\prime}$ yang termaktub dalam surah

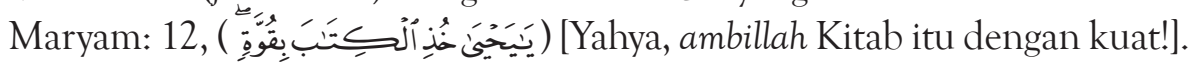

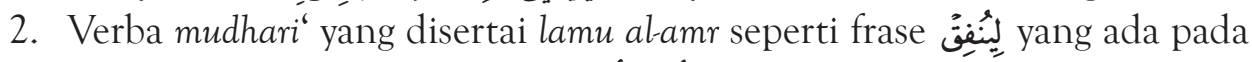

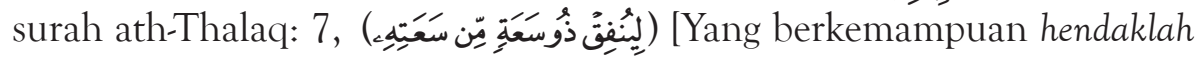
berinfak sesuai dengan kemampuannya].

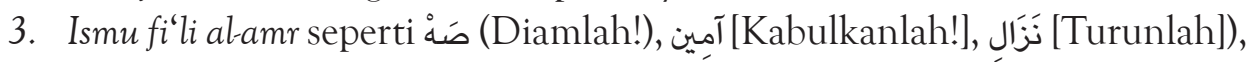
دَرَاكِ [Susullah!], dan lain-lain.

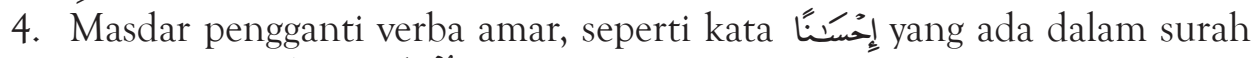

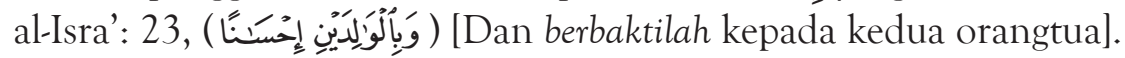

Namun, Giv (2016) menyebutkan bahwa dalam al-Quran wujud lingual imperatif bisa beragam, tidak hanya menggunakan keempat variasi tersebut, tetapi boleh jadi berupa kalimat deklaratif atau interogatif. Bahkan, tuturan imperatif yang menggunakan bentuk interogatif terkadang mengantarkan makna yang lebih tegas dan kuat karena menghadirkan implikatur tertentu yang tidak bisa dihadirkan dalam bentuk imperatif biasa.

Sedikit berbeda, al-Hasyimi (2001) serta al-Jarim \& Amin (2007) menakrifkan imperatif sebagai tuturan yang berisi tuntutan supaya mitra tutur merealisasikan suatu tindakan sebagai pengejawantahan superioritas penutur. Sekaitan dengan ini boleh jadi penutur benar-benar berada dalam - meminjam istilah Eggins (2004) - kontinum power yang lebih tinggi atau sekadar merasa dirinya lebih tinggi ketimbang mitra tutur. Dalam hal ini kontinum power mencandrakan ke(tak)setaraan relasi sosial antara penutur dan mitra tutur.

el Harakah Jurnal Budaya Islam Vol. 19 No.2 Tahun 2017 


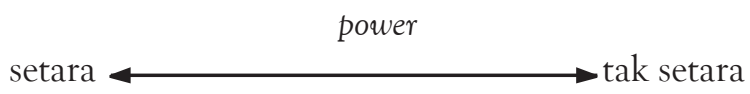

Gambar 1. Kontinum Power (Eggins, 2004)

Dalam pemakaian, makna sebuah tuturan tidak selalu bergantung pada konstruksi kalimatnya. Tuturan imperatif juga tidak selalu menghadirkan makna imperatif berupa perintah atau suruhan, tetapi adakalanya dimaksudkan untuk menghadirkan makna pragmatik tertentu. Makna pragmatik imperatif ini ditentukan oleh koteks (siyaqu al-kalam) dan konteks (qarainu al-ahwal) yang melatarinya. Kehadiran koteks dan konteks dalam suatu peristiwa tutur sangat penting lantaran berkaitan dengan pemahaman mitra tutur terhadap maksud sebuah tuturan sebagaimana yang dikehendaki penuturnya. Mey (2008: 38) mendefinisikan istilah konteks sebagai "the surroundings, in the widest sense, that enable the participants in the communication process to interact, and that make the linguistic expressions of their interaction intelligible." Sekaitan dengan inilah "Utsaimin (2013) menegaskan bahwa makna sebuah tuturan imperatif dalam BA boleh jadi bergeser dari makna asalnya bila terdapat indikasi tertentu, baik berupa koteks maupun konteks yang melatari tuturan tersebut. Istilah koteks lazim merujuk kepada unsur-unsur yang bersifat intralinguistik, sedangkan istilah konteks lazim merujuk kepada faktor-faktor yang bersifat ekstralinguistik atau berada di luar bahasa. Yang terakhir ini meliputi peserta tutur (penutur dan mitranya), situasi tutur, maksud tuturan, lingkungan tutur, dan sebagainya.

Keberadaan koteks dan konteks tertentu dapat menggeser makna sebuah tuturan imperatif dari dalalah ashliyyah (basic meaning) kepada dalalah tabiiiyyah (secondary meaning) yang dikehendaki tuturan tersebut. Sekaitan dengan ini Rahardi (2010) menggunakan istilah wujud formal imperatif dan wujud pragmatik imperatif. Wujud formal imperatif digunakan untuk menyebut realisasi maksud imperatif menurut ciri strukturalnya. Namun, kehadiran konteks tertentu dapat menyebabkan tuturan imperatif mempunyai makna pragmatik yang beragam. Karena itu, wujud formal imperatif bisa berbeda dengan wujud pragmatiknya. Demikian pula tuturan imperatif dalam BA adakalanya mempunyai dalalah tabi i iyyah yang berbeda dengan dalalah ashliyyahnya. Di satu sisi dalalah ashliyyah dapat dipahami dari konstruksi kalimat yang membentuk suatu tuturan. Di sisi lain dalalah tabi'iyyah atau makna pragmatik dapat dipahami dari koteks atau konteks yang melatarinya. Menurut al-Hasyimi (2001), kehadiran dalalah tabi'iyyah dalam suatu tuturan imperatif dapat dipahami dari al-lafzh (kata), al-isyarah (isyarat), al-kitabah (pesan), al'uqad (alur), dan al-hal (konteks). 
Pendapat al-Qazwaini (2011) menyatakan bahwa dalam BA wujud formal imperatif adakalanya tidak digunakan untuk mengungkapkan maksud thalab (tuntutan) lantaran keberadaan koteks atau konteks yang melatarinya, tetapi digunakan untuk menghadirkan aneka makna pragmatik seperti at-tahdid (mengancam), al-ihtiqar (menyepelekan), dan sebagainya. Lebih lengkap alHasyimi (2001) menyenaraikan aneka makna pragmatik tuturan imperatif sebagaimana berikut ini.

1. Ad-du'a (berdoa), sebagaimana firman Allah swt. yang termaktub dalam

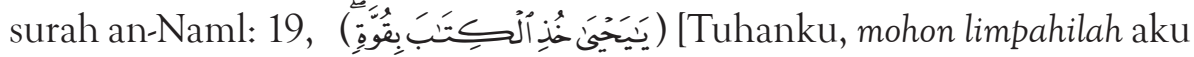
rahmat untuk senantiasa mensyukuri nikmat-Mu].

2. Al-iltimas (meminta), misalnya tuturan Anda kepada kawan sebaya, أعطني [Tolong berikan balpoin itu kepada saya, kawan!].

3. Al-irsyad (membimbing), sebagaimana firman Allah swt. dalam surah al-

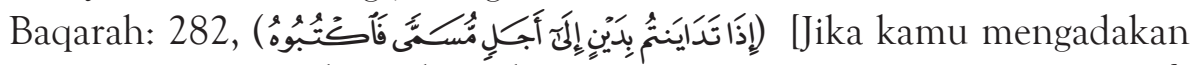
utang-piutang untuk jangka waktu tertentu, hendaklah kamu mencatatnya].

4. At-tahdid (mengancam), sebagaimana firman Allah swt. dalam surah

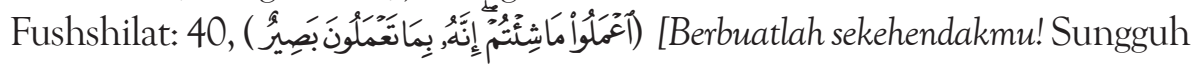
Dia Maha Melihat apa yang kamu perbuat].

5. At-ta'jiz (melemahkan), sebagaimana firman Allah swt. dalam surah al-

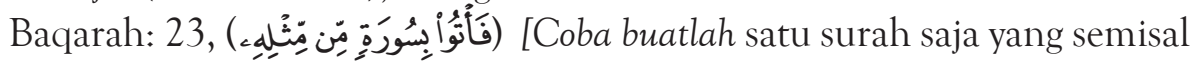
dengannya].

6. Al-ibahah (memperbolehkan), misalnya firman Allah swt. dalam surah al-

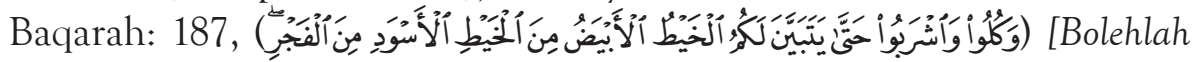
kalian makan-minum hingga jelas benang putih daripada benang hitam, yaitu fajar].

7. Al-taswiyah (mempersamakan), seperti firman Allah swt. dalam surah

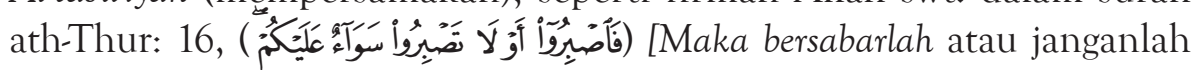
bersabar itu sama saja bagi kalian].

8. Alikram (memuliakan), sebagaimana firman Allah swt. dalam surah al-Hijr:

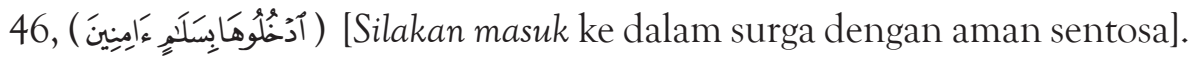

9. Al-imtinan (menganugerahkan), misalnya firman Allah swt. dalam surah

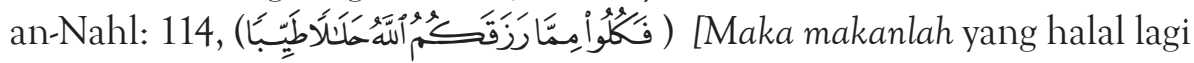
baik dari rezeki yang telah dianugerahkan Allah kepada kalian].

10. Alihanah (menghinakan) sebagaimana firman Allah swt. dalam surah al-

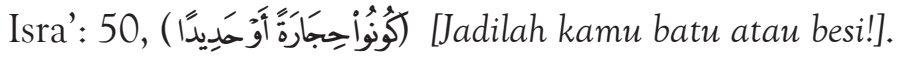

el Harakah Jurnal Budaya Islam Vol. 19 No.2 Tahun 2017 
11. Ad-dawam [menyinambungkan] seperti firman Allah swt. dalam surah

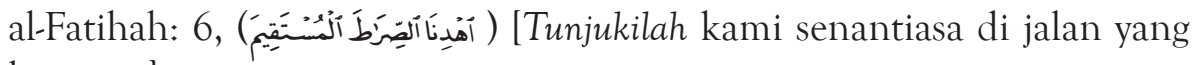
lempang].

12. At-tamanniy (berangan-angan), seperti syair Umru' al-Qais berikut ini. [Duhai malam yang panjang, janganlah engkau menyingsing] \# بصبح وما الإصباح منك بأمثل الطايل ]karena subuh, sebab penampakan subuh terhadap engkau tiadalah sebanding].

13. Al-i'tibar (memberi ibrah) sebagaimana firman Allah swt. dalam surah

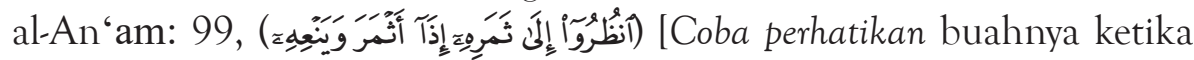
berbuah].

14. Alidzn (mengizinkan), seperti tuturan Anda kepada seseorang yang mengetuk pintu, "ادخل" [Silakan masuk!].

15. At-takwin (menjadikan), seperti firman Allah swt. yang terdapat dalam

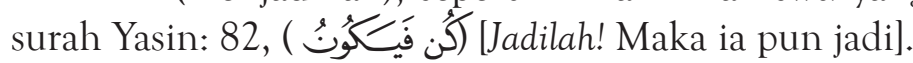

16. At-takhyir (memilih), misalnya tuturan, "تزوج هندا أو أختها" [Nikahilah Hindun atau saudaranya].

17. At-ta'dib (mendidik), misalnya tuturan, "كل مما يليك" [Sebaiknya makanlah makanan yang dekat denganmu].

18. At-ta'ajjub (menakjubkan), sebagaimana firman Allah swt. dalam surah al-

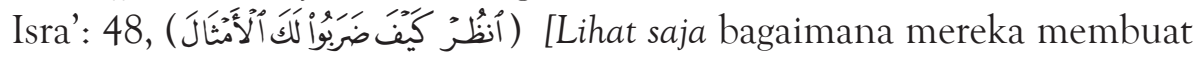
perumpamaan untukmu].

Sedikit berbeda dengan al-Hasyimi yang hanya menyebutkan 18 makna pragmatik, as-Suyuthi (1966) mengemukakan bahwa dalam BA tuturan imperatif mempunyai 20 makna pragmatik sesuai dengan koteks atau konteks yang melatarinya. Tambahan yang dikemukakan as-Suyuthi adalah makna pragmatik al-indzar (memberi peringatan) seperti yang termaktub dalam surah al-Mursalat: 46, dan makna pragmatik al-ihtiqar (menyepelekan) seperti yang termaktub dalam surah Yunus: 80 . Dalam menentukan jumlah makna pragmatik ayat imperatif, penelitian ini merujuk kepada pendapat as-Suyuthi yang mengatakan bahwa ayat-ayat imperatif al-Quran mempunyai 20 makna pragmatik.

\section{Metode Penelitian}

Pada dasarnya penelitian ini merupakan penelitian tentang penerjemahan yang bersifat deskriptif dan berorientasi kepada terjemahan sebagai produk kognitif. Rancangan penelitian ini menggunakan pendekatan kualitatif-evaluatif dengan desain embedded case study research (penelitian studi kasus terpancang). 
Sampel penelitian dipilih secara purposif sesuai dengan tujuan penelitian dan ditetapkan berdasarkan kriteria tertentu. Sekaitan dengan ini sampel penelitian berupa 20 ayat imperatif bernuansa budaya yang masing-masing memiliki makna pragmatik tertentu.

Penelaahan berfokus pada terjemahan ayat-ayat imperatif yang terdapat dalam terjemah Kemenag (Al-Qur'an dan Terjemahnya). Ada dua kategori data yang digunakan dalam penelitian ini. Pertama, data berupa kata, frase, dan klausa yang terdapat dalam 20 ayat imperatif al-Quran beserta terjemahannya. Analisis terhadap data ini dimaksudkan untuk mengungkap penerapan teknik dan prosedur penerjemahan yang digunakan dalam menangani ayat-ayat imperatif bernuansa budaya. Kedua, data berupa persepsi responden ihwal ketedasan terjemahan ayat-ayat imperatif, yang dihimpun dengan menggunakan kuesioner derajat ketedasan terjemahan. Dalam hal ini ketedasan berhubungan dengan keterpahaman bahasa terjemahan yang ditentukan oleh alur pikir, susunan paragraf, konstruksi kalimat, pungtuasi, kolokasi, diksi, dan unsurunsur ketatabahasaan lainnya. Ketedasan terjemahan juga diukur dengan menggunakan uji rumpang yang mencakup kriteria independen (benar $\geq 50 \%$ ), instruksional (benar antara 30\%-49\%), atau frustasi (benar <30\%).

\section{Temuan dan Pembahasan}

Penerjemahan dapat dipandang sebagai pengalihan informasi yang terdapat dalam BS ke dalam BT. Pengalihan informasi ke dalam BT meniscayakan terpenuhinya aspek ketedasan. Dalam penerjemahan, menghadirkan ketedasan sama pentingnya dengan menghadirkan keakuratan. Bukan tidak mungkin sebuah teks terjemahan sudah memenuhi aspek keakuratan, tetapi tidak menghadirkan ketedasan yang memadai bagi pembacanya. Ketaktedasan menyebabkan informasi BS tidak tersampaikan secara utuh karena teks terjemahan sulit atau tidak dapat dipahami. Aspek ketedasan berhubungan dengan keterbacaan dan keterpahaman informasi yang terdapat dalam sebuah teks terjemahan.

\section{Ketedasan Terjemahan Ayat-ayat Imperatif}

Derajat ketedasan berkenaan dengan seberapa mudah pembaca memahami informasi yang terdapat dalam sebuah teks terjemahan. Sebuah teks terjemahan dikatakan mudah dipahami pembacanya manakala memiliki derajat keterbacaan yang tinggi. Jadi, aspek ketedasan berkenaan dengan keterbacaan bahasa terjemahan yang mencakup unsur-unsur yang hadir di

el Harakah Jurnal Budaya Islam Vol. 19 No.2 Tahun 2017 
dalamnya seperti alur pikir, konstruksi kalimat, dan unsur-unsur ketatabahasaan lainnya. Tanggapan responden sangat bermanfaat untuk mengetahui derajat ketedasan terjemahan ayat-ayat imperatif. Dalam kapasitas sebagai penutur asli $\mathrm{BI}$, para responden mengemukakan tanggapannya atas terjemahan ayat-ayat imperatif yang termaktub dalam terjemah Kemenag dengan memberi penilaian tedas, kurang tedas, atau tak tedas. Pertama, suatu terjemahan ayat imperatif dipandang tedas manakala alur pikir, konstruksi kalimat, dan unsur-unsur ketatabahasaan yang ada dalam terjemahan tersebut dapat dipahami dengan mudah. Kedua, suatu terjemahan ayat imperatif dipandang kurang tedas manakala secara umum terjemahan tersebut dapat dipahami, tetapi masih ada alur pikir, konstruksi kalimat, atau unsur-unsur ketatabahasaan lain yang kurang dapat dipahami. Ketiga, suatu terjemahan ayat imperatif dipandang tak tedas manakala alur pikir, konstruksi kalimat, dan unsur-unsur ketatabahasaan yang ada dalam terjemahan tersebut sulit dipahami.

Temuan penelitian ini menunjukkan bahwa secara umum terjemahan ayat-ayat imperatif bernuansa budaya dalam terjemah Kemenag mempunyai derajat ketedasan yang tinggi. Hal ini ditunjukkan oleh rerata ketedasan terjemahan ayat-ayat imperatif yang mencapai $84,8 \%$. Artinya, terjemahan ayat-ayat imperatif dalam terjemah Kemenag ini dapat dipahami oleh pembaca dengan mudah. Derajat ketedasan terjemahan ayat-ayat imperatif dalam terjemah Kemenag tercandrakan dalam tabel berikut.

Tabel 1. Ketedasan terjemahan ayat-ayat imperatif

\begin{tabular}{llc}
\hline No. & $\begin{array}{l}\text { Terjemahan Ayat Imperatif } \\
\text { Bernuansa Budaya }\end{array}$ & $\begin{array}{c}\text { Derajat Ketedasan } \\
(\%)\end{array}$ \\
\hline 1 & Q.S. al-Baqarah: 201 & 90,0 \\
2 & Q.S. Luqman: 17 & 83,3 \\
3 & Q.S. Ibrahim: 30 & 82,2 \\
4 & Q.S. al-Baqarah: 23 & 87,8 \\
5 & Q.S. al-Baqarah: 168 & 93,3 \\
6 & Q.S. al-Mulk: 13 & 80,0 \\
7 & Q.S. al-Hijr: 45-46 & 88,9 \\
8 & Q.S. an-Nahl: 114 & 90,0 \\
9 & Q.S. al-Mu'minun: 107-108 & 83,3
\end{tabular}




\begin{tabular}{lll}
10 & Q.S. al-Fatihah: 6 & 92,2 \\
11 & Q.S. Yunus: 101 & 83,3 \\
12 & Q.S. al-Isra': 48 & 83,3 \\
13 & Q.S. Ghafir: 68 & 86,7 \\
14 & Q.S. Yusuf: 9 & 75,6 \\
15 & Q.S. az-Zukhruf: 77 & 82,2 \\
16 & Q.S. Yusuf: 21 & 82,2 \\
17 & Q.S. al-Mursalat: $45-46$ & 84,4 \\
18 & Q.S. Yunus: 80 & 83,3 \\
19 & Q.S. Qaf: 23-24 & 77,8 \\
20 & Q.S. Ali Imran: 93 & 85,6 \\
\hline Rerata & & 84,8 \\
\hline
\end{tabular}

Selain meminta tanggapan responden, dalam penelitian ini derajat ketedasan terjemahan ayat-ayat imperatif juga ditelaah dengan menggunakan uji rumpang. Penggunaan uji rumpang dimaksudkan untuk mengungkap apakah ketedasan terjemahan ayat-ayat imperatif bernuansa budaya berada pada level independen, instruksional, dan frustasi. Level independen menunjukkan bahwa pembaca dapat memahami terjemahan ayat-ayat imperatif secara mandiri; level instruksional menunjukkan bahwa pembaca dapat memahami terjemahan ayat-ayat imperatif dengan bantuan orang lain; dan level frustasi menunjukkan bahwa pembaca mengalami kesulitan dalam memahami terjemahan ayat-ayat imperatif bernuansa budaya.

Secara keseluruhan, terjemahan ayat-ayat imperatif dalam terjemah Kemenag yang menjadi sampel penelitian memuat 2.660 kata. Dalam penelitian ini, pelaksanaan uji rumpang melibatkan 40 responden. Setelah memelajari terjemahan ayat-ayat imperatif tersebut, responden diminta untuk melengkapi bagian-bagian teks terjemahan yang dikosongkan secara sitematis. Hasil uji rumpang menunjukkan bahwa 78,9\% responden dapat melengkapi bagian-bagian terjemahan yang dikosongkan dengan benar. Persentase ini menunjukkan bahwa terjemahan ayat-ayat imperatif bernuansa budaya dalam terjemah Kemenag berada pada level independen, sebab jumlah jawaban yang benar lebih daripada separuhnya. Level independen ini berarti pembaca dapat memahami terjemahan ayat-ayat imperatif bernuansa budaya dalam terjemah Kemenag secara mandiri tanpa memerlukan bantuan orang lain. 
Ketedasan terjemahan ayat-ayat imperatif bernuansa budaya tidak terlepas dari penerapan teknik dan prosedur penerjemahan yang digunakan dalam menangani unit-unit mikro terjemahan. Misalnya ketika menangani pronomina

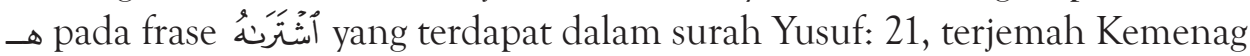
menerapkan teknik literal, hatta frase tersebut diterjemahkan menjadi membelinya. Penerapan teknik literal ini ternyata mencederai ketedasan terjemahan ayat imperatif tersebut. Pembaca terjemahan boleh jadi mencari-cari anteseden yang menjadi rujukan pronomina nya dalam terjemahan tersebut, sebab pronomina nya yang bersifat anaforis ini merujuk kepada Yusuf yang termaktub pada ayat

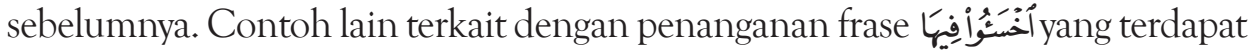
dalam surah al-Mu'minun: 108. Dalam hal ini terjemah Kemenag menangani frase فِ فِيَّا juga dengan menerapkan teknik literal. Hasilnya, penggalan ayat ini diterjemahkan menjadi tinggallah dengan hina di dalamnya. Keberadaan frase di dalamnya ternyata dipandang mencederai ketedasan terjemahan ayat imperatif tersebut, sebab pronomina nya yang bersifat anaforik ini juga tidak merujuk kepada unsur linguistik yang jelas dalam terjemahan ayat tersebut.

Selain dengan menerapkan teknik literal, upaya memertahankan unsur-unsur BS dalam BT juga dilakukan terjemah Kemenag dengan menerapkan teknik kalke. Teknik kalke yang lazim diterapkan pada tataran frase ini sesungguhnya tidak begitu berbeda dengan teknik literal dalam hal kesetiaannya kepada BS. Sebagai contoh dalam terjemah Kemenag, frase

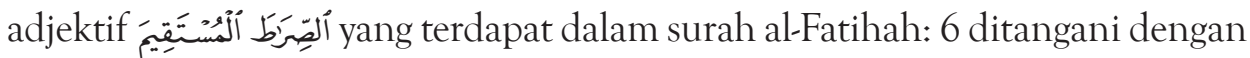
teknik kalke, frase tersebut diterjemahkan menjadi jalan yang lurus. Ketedasan terjemahan frase ini sesungguhnya relatif kurang berterima jika ditangani dengan menerapkan prosedur tunggal, yakni hanya menerapkan teknik kalke. Berterimanya ketedasan terjemahan frase ini diperoleh berkat penerapan prosedur kuplet yang memadukan teknik kalke dengan teknik amplifikasi. Penerapan teknik amplifikasi hadir dalam bentuk pemberian catatan kaki yang mengorak lebih jauh maksud dari jalan yang lurus, yaitu jalan hidup yang benar, yang dapat membuat bahagia di dunia dan akhirat. Berkat keberadaan catatan kaki, terjemahan ayat ini mempunyai derajat ketedasan yang tinggi. Hal ini sejalan dengan penelitian Syihabuddin (2005) yang mengungkapkan bahwa keterpahaman teks terjemahan antara lain dapat dilakukan dengan memberi penjelasan terhadap ungkapan-ungkapan yang bersifat khusus.

Penerapan teknik penerjemahan berimplikasi terhadap derajat ketedasan terjemahan. Temuan penelitian menunjukkan bahwa transposisi termasuk salah satu teknik penerjemahan yang relatif dapat meningkatkan derajat 
ketedasan terjemahan. Teknik transposisi lazim dipergunakan untuk mengubah kategori gramatikal, misalnya keterangan menjadi verba (lihat Molina \& Albir, 2002). Perubahan kategori gramatikal dilakukan lantaran perbedaan BS dan BT, terutama yang berasal dari rumpun bahasa yang berbeda, pada tataran gramatika. Perbedaan BS dan BT meniscayakan terjadinya penyesuaian (adjustment) dalam penerjemahan, baik pada tataran level, struktur, maupun kategori. Sebagai contoh, makna pragmatik alibahah (membolehkan) bisa

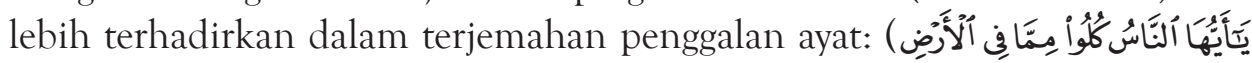
(مَكَلًَ طَيَبًَا yang terdapat dalam surah al-Baqarah: 168 dengan menerapkan teknik transposisi. Verba كُو teknik transposisi dapat diterjemahkan menjadi kalian boleh makan. Meskipun penerapan teknik ini menyebabkan pergeseran kategori dari verba imperatif menjadi verba aktif biasa, tetapi makna al-ibahah dalam terjemahan terasa lebih hadir. Dengan begitu, terjemahan ayat ini akan lebih tedas apabila diterjemahkan menjadi, Wahai manusia, kalian boleh makan sebagian makanan yang halal lagi baik.

\section{Simpulan}

Terjemah Kemenag menangani ayat-ayat imperatif bernuansa budaya dengan menggunakan strategi source language approach. Penggunaan strategi ini menyebabkan nuansa BS terasa hadir dalam terjemahan. Namun demikian, ketedasan terjemahan ayat-ayat imperatif dalam terjemah Kemenag hadir antara lain berkat prosedur tunggal yang menerapkan teknik transposisi. Selain itu, penerapan prosedur kuplet yang memadukan teknik kalke dengan teknik amplifikasi juga dipandang menghadirkan ketedasan yang tinggi. Dengan teknik kalke, sebuah frase yang terdapat dalam suatu ayat imperatif diterjemahkan secara harfiah dengan meminjam bentuk ekspresi yang digunakan BS. Dengan menerapkan teknik amplifikasi, terjemahan harfiah ini kemudian diorak lebih jauh dalam sebuah komentar, baik dalam bentuk penjelasan dalam kurung, taklikat, takarir, hasyiah, catatan kaki, ataupun catatan akhir. Secara umum terjemahan ayat-ayat imperatif bernuansa budaya dalam terjemah Kemenag mempunyai derajat ketedasan yang berterima. Hal ini juga diperkuat dengan hasil uji rumpang yang menyebutkan bahwa ketedasan terjemahan ayat-ayat imperatif bernuansa budaya dalam terjemah Kemenag berada pada level independen.

Secara teoretis, menghadirkan ketedasan terjemahan tidak selalu harus dengan menerapkan teknik-teknik penerjemahan yang berorientasi kepada 
BT, semisal modulasi, amplifikasi linguistik, dan semacamnya, tetapi bisa juga dengan menerapkan prosedur kuplet yang memadukan teknik literal dengan salah satu teknik penerjemahan yang berorientasi kepada BT. Cara ini dipandang tidak hanya dapat menghadirkan ketedasan terjemahan, tetapi juga keakuratan terjemahan. Dalam praktik, menakar ketedasan terjemahan dengan meminta tanggapan pembaca BT dipandang lebih efektik ketimbang, misalnya, hanya menggunakan uji rumpang atau indeks kabut saja.

\section{Daftar Pustaka}

Al Farisi, M.Z. 2010. Keterjemahan Ungkapan Kinayah dalam Bahasa Arab ke dalam Bahasa Indonesia. Bahasa $\mathcal{E}$ Sastra 10(2), 188-200.

Al Farisi, M.Z. 2011. Pedoman Penerjemahan Arab-Indonesia: Strategi, Metode, Prosedur, Teknik. Bandung: PT Remaja Rosdakarya.

Al Farisi, M.Z. 2013. Aspek Relevansi dalam Terjemahan Tindak-tutur Kinayah al-Qur'an. KARSA: Jurnal Sosial \& Budaya Keislaman 2(21), 156-169.

Al Farisi, M.Z. 2015. Speech Act of Iltifat and its Indonesian Translation Problem. Indonesian Journal of Applied Linguistics (IJAL) 4(2), 214-225.

Al-Hasyimi, A. 2001. Jawahiru al-Balaghati fi al-Ma'ani wa al-Bayani wa al-Badit Beirut: Daru al-Kutubi al-'Ilmiyyah.

Al-Jarim, 'A. \& Amin, M. 2007. Al-Balaghatu al-Wadhihah. Kairo: Dar al-Ma'arif. Alisjahbana, S.T. 1978. Tatabahasa Baru Bahasa Indonesia. Jakarta: Penerbit Dian Rakyat.

Al-Qazwaini, J. 2011. Al-Idhahu fi 'Ulumi al-Balaghah. Beirut: Daru al-Jail.

Ash-Shawi, M.A. 2013. Translating Euphemisms: Theory and Application. Journal of American Arabic Academy for Sciences and Technology 4(8), 123-132.

As-Suyuthi, J. 1966. Al-Itqanu fi 'Ulumi al-Qur'an. Kairo: Daru al-Syuruq.

Cummings, L. 2005. Pragmatics: A Mutidisiplinary Perspective. New Jersey: Lawrence Erlbaum Associates Publisher.

Eggins, S. 2004. An Introduction to Systemic Fungtional Linguistics (Second edition). London: Continuum. 
Flesch, R. 2005. How to Write, Speak and Think More Effectively. New American Library.

Garces, C.V. 2008. Translating the Imaginary World in the Harry Potter Series on How Muggles, Quaffles, Snitches, and Nickles Travel to Other Cultures. Revista de Traduccio 9(1), 121-134.

Ghalayaini, M. 2010. Jami' ad-Durusi al-Arabiyyah. Beirut: Muassasatu al-Risalati Nasyirun.

Giv, A.L. 2016 Exchange of Linguistic Forms: Imperative Forms Indicating Interrogation and Declarative Statement: The Instances in Quran. Mediterranean Journal of Social Sciences 7(3), 456-464.

Huzairi, A. \& Ibrahim, M.H. 2009. Al-Mabadi al-Asasiyyatu fi Tarjamati al-Qurani al-Karim fi Dhaui Mu'thiyati al-Tarjamah al-Haditsah. 'Ain: Majallah al-Jam'iyyah al-'Ilmiyyah al-Su'udiyyah li al-Lughati wa al-Tarjamah, 3(1), 13-48.

Keraf, G. 1980. Tata Bahasa Indonesia untuk Sekolah Lanjutan Atas. Ende: Nusa Indah.

Larson, M.L. 1998. Meaning-Based Translation: A Guide to Cross-Language Equivalence (Second edition). Boston: University Press of America.

Mey, J. 2008. Pragmatics: An Introduction. Cambridge: Blackwell Publisher.

Moeliono, A.M. 1992. Tata Bahasa Baku Bahasa Indonesia. Jakarta: Perum Balai Pustaka.

Molina, L. \& Albir, A. H. 2002. Translation Techniques Revisited: A Dynamic and Functionalist Approach. Meta Journal des Traducteur 47(4), 498-512.

Peodjawijatna, I.R. \& Zoetmulder, P.J. 1964. Tatabahasa Indonesia untuk Sekolah Landjutan Atas. Djakarta: N.V. Obor.

Rahardi, K. 2010. Pragmatik Kesantunan Imperatif Bahasa Indonesia. Jakarta: Erlangga.

Ramlan, M. 1987. Ilmu Bahasa Indonesia, Sintaksis. Yogyakarta: CV Karyono.

Richards, J., Plat, J., \& Weber, H. 2005. Longman Dictionary of Applied Linguistics. Harlow: Longman.

el Harakah Jurnal Budaya Islam Vol. 19 No.2 Tahun 2017 
Sakri, A. 2006. Bangun Kalimat Bahasa Indonesia. Bandung: Penerbit ITB.

Seong, G.S. 2011. Penerjemahan Kata Kerja Bahasa Cina-Bahasa Melayu: Satu Analisis Ketepatan Makna Padanan. Gema Online Journal of Language Studies 11(1), 35-56.

Shanmugam, K. 2010. Pantun Translation into English in Women's Writings in Twentieth Century British Malaya. Journal of Modern Languages 20(1), 80-93.

Slametmuljana. 1959. Kaidah Bahasa Indonesia II. Ende: Penerbit Nusa Indah.

Syihabuddin. 2005. Penerjemahan Arab-Indonesia (Teori dan Praktek). Bandung: Humaniora.

Thriveni, C. 2002. Cultural Elements in Translation: The Indian Perspective. Translation Journal and the Authors 6(1), 83-98.

'Utsaimin, M.S. 2013. Syarh al-Balaghah min Kitabi Qawa'id al-Lughati al'Arabiyyah. Riyadh: Muassasatu asy-Syaikh Muhammad ibn Shalih al'Utsaimin al-Khairiyyah.

Verhaar, J.W.M. 2008. Asas-Asas Linguistik Umum. Yogyakarta: Gadjah Mada Univesity Press.

Xiao-yan, W. 2013. Translating Tourism Texts in the Light of Skopos Theory. US-China Foreign Language 11 (3), 254-263. 